\title{
Psychrotolerant Mesorhizobium sp. Isolated from Temperate and Cold Desert Regions Solubilizes Potassium and Produces Multiple Plant Growth Promoting Metabolites
}

\author{
Zahoor Ahmad Baba ${ }^{1}$, Basharat Hamid ${ }^{1, *}{ }^{\oplus}$, Tahir Ahmad Sheikh ${ }^{2}{ }^{\circ}$, Saad H. Alotaibi ${ }^{3}{ }^{\mathbb{D}}$, \\ Hesham A. El Enshasy ${ }^{4,5, *}$, Mohammad Javed Ansari ${ }^{6}{ }^{\mathbb{D}}$, Ali Tan Kee Zuan $7, * \mathbb{C}$ and R. Z. Sayyed $8, * \mathbb{C}$
}

1 Division of Basic Science and Humanities, Faculty of Agriculture, Sher-e-Kashmir University of Agricultural Sciences and Technology, Sopore 193201, India; baba.zahoor@gmail.com

2 Division of Agronomy, Faculty of Agriculture, Sher-e-Kashmir University of Agricultural Sciences and Technology of Kashmir, Sopore 193201, India; tahirkmr@gmail.com

3 Department of Chemistry, Turabah University College, Taif University, P. O. Box 11099, Taif 21944, Saudi Arabia; s.alosaimi@tu.edu.sa

4 Institute of Bioproduct Development (IBD), University Teknologi Malayisa (UTM), Skudai 81310, Johor, Malaysia

5 City of Scientific Research and Technology Applications (SRTA), New Burg Al Arab, Alexandria 21934, Egypt

6 Department of Botany, Hindu College, Mahatma Jyotiba Phule Rohilkhand University Bareilly, Moradabad 244001, India; mjavedansari@gmail.com

7 Department of Land Management, Faculty of Agriculture, University Putra Malaysia, (UPM), Serdang 43400, Selangor, Malaysia

check for updates

Citation: Baba, Z.A.; Hamid, B.; Sheikh, T.A.; Alotaibi, S.H.; El Enshasy, H.A.; Ansari, M.J.; Zuan, A.T.K.; Sayyed, R.Z. Psychrotolerant Mesorhizobium sp. Isolated from Temperate and Cold Desert Regions Solubilizes Potassium and Produces Multiple Plant Growth Promoting Metabolites. Molecules 2021, 26, 5758. https://doi.org/10.3390/ molecules26195758

Received: 19 August 2021 Accepted: 19 September 2021 Published: 23 September 2021

Publisher's Note: MDPI stays neutral with regard to jurisdictional claims in published maps and institutional affiliations.

Copyright: (C) 2021 by the authors Licensee MDPI, Basel, Switzerland. This article is an open access article distributed under the terms and conditions of the Creative Commons Attribution (CC BY) license (https:// creativecommons.org/licenses/by/ $4.0 /)$.
8 Department of Microbiology, PSGVP Mandal's Arts, Science and Commerce College, Shahada 425409, India

* Correspondence: basharat384@gmail.com (B.H.); henshasy@ibd.utm.my (H.A.E.E.); tkz@upm.edu.my (A.T.K.Z.); sayyedrz@gmail.com (R.Z.S.)

\begin{abstract}
Soil potassium (K) supplement depends intensively on the application of chemical fertilizers, which have substantial harmful environmental effects. However, some bacteria can act as inoculants by converting unavailable and insoluble $\mathrm{K}$ forms into plant-accessible forms. Such bacteria are an eco-friendly approach for enhancing plant $\mathrm{K}$ absorption and consequently reducing utilization of chemical fertilization. Therefore, the present research was undertaken to isolate, screen, and characterize the K solubilizing bacteria (KSB) from the rhizosphere soils of northern India. Overall, 110 strains were isolated, but only 13 isolates showed significant K solubilizing ability by forming a halo zone on solid media. They were further screened for $\mathrm{K}$ solubilizing activity at $0{ }^{\circ} \mathrm{C}, 1{ }^{\circ} \mathrm{C}, 3{ }^{\circ} \mathrm{C}, 5{ }^{\circ} \mathrm{C}, 7{ }^{\circ} \mathrm{C}, 15^{\circ} \mathrm{C}$, and $20{ }^{\circ} \mathrm{C}$ for 5,10 , and 20 days. All the bacterial isolates showed mineral $\mathrm{K}$ solubilization activity at these different temperatures. However, the content of $\mathrm{K}$ solubilization increased with the upsurge in temperature and period of incubation. The isolate KSB (Grz) showed the highest K solubilization index of $462.28 \%$ after $48 \mathrm{~h}$ of incubation at $20{ }^{\circ} \mathrm{C}$. The maximum of $23.38 \mu \mathrm{g} \mathrm{K} / \mathrm{mL}$ broth was solubilized by the isolate $\mathrm{KSB}$ (Grz) at $20{ }^{\circ} \mathrm{C}$ after 20 days of incubation. Based on morphological, biochemical, and molecular characterization (through the 16S rDNA approach), the isolate KSB (Grz) was identified as Mesorhizobium sp. The majority of the strains produced $\mathrm{HCN}$ and ammonia. The maximum indole acetic acid (IAA) $(31.54 \mu \mathrm{M} / \mathrm{mL})$ and cellulase $(390 \mu \mathrm{M} / \mathrm{mL})$ were produced by the isolate KSB (Grz). In contrast, the highest protease $(525.12 \mu \mathrm{M} / \mathrm{mL})$ and chitinase $(5.20 \mu \mathrm{M} / \mathrm{mL})$ activities were shown by standard strain Bacillus mucilaginosus and KSB (Gmr) isolate, respectively.
\end{abstract}

Keywords: potassium solubilization; Mesorhizobium sp.; plant growth promoting traits; cellulase; rhizosphere

\section{Introduction}

Potassium $(\mathrm{K})$ is one of the main macronutrients and the most abundant cation in higher plants [1], with significant absorption that plays a vital role in metabolic activity, 
activation of $\sim 80$ enzymes, starch synthesis, sugar degradation, photosynthesis, disease resistance, etc. [2,3]. There are four $\mathrm{K}$ forms found in the soil, namely, soil minerals, nonexchangeable, exchangeable, and water soluble [4]. Soil minerals make up approximately 90 to $98 \%$ of soil K, which is tightly bound and predominantly unavailable for plant uptake [5,6]. Approximately $10 \%$ of the soil $\mathrm{K}$ consists of the interlayer of the non-expanded form of K-bearing minerals, such as illite, mica, and feldspar [7,8]. Among the diverse $\mathrm{K}$ forms in soil, the concentration of soluble $\mathrm{K}$ is usually deficient (1 to $2 \%$ ) $[9,10]$. Plants primarily absorb $\mathrm{K}$ from the soil, and its availability is generally governed by the $\mathrm{K}$ dynamics and its total content. The release of non-exchangeable $\mathrm{K}$ to the exchangeable form arises when exchangeable and solution $\mathrm{K}$ levels are diminished by crop removal, erosion or leaching, and runoff $[11,12]$. Only a small fraction of the $\mathrm{K}$ requirements of the plant is attained by direct contact through root interception, and the major fraction $(90 \%)$ is held in insoluble forms [13]. The majority of the K required by plants must be transported in the soil to the roots [14], and the movement of $\mathrm{K}$ ions is a significant element in the supply of $\mathrm{K}$. This transport happens mostly in soil fluid, the liquid phase of the soil, by mass flow (with the water going to the roots of a plant) and diffusion through the concentration gradient created by the absorbent surface, i.e., roots. Near the roots, the soil solution is rapidly exhausted of nutrients due to removal by the plants $[15,16]$. Among the different $\mathrm{K}$ forms, the most available to plants and microbes are the soluble and exchangeable forms [10]. The available fraction of $\mathrm{K}$ is also susceptible to fixation through electrostatic attraction between negatively charged clay lattice layers and $\mathrm{K}^{+}$ions, besides expansive forces due to ion hydration [17]. The minerals primarily accountable for the fixation of $\mathrm{K}$ ions include montmorillonite, vermiculite, and weathered mica. The amount of $\mathrm{K}$ fixation is directly proportional to the charge density of the interlayer surface of the clay lattice. Hydrous mica clays have been found to fix huge quantities of $K$, which could not be released even with boiling $\mathrm{HNO}_{3}$ [8].

Growing amounts of high-yielding fertilizer responsive crop varieties and the intensification of agriculture have led to the depletion of available reserves of various nutrients, including $\mathrm{K}$, at an alarming rate. Imbalanced fertilizer application is also a prominent contributing factor to the K deficiency in agricultural soils. These issues have enabled a new research frontier focused on the discovery of an alternative natural, sustainable and safe method for improving K availability by exploring the plant-growth-promoting bacteria (PGPB) that stimulate plant growth through nitrogen (N) fixation, mineral solubilization (phosphorus, potassium and zinc), organic matter degradation, and phytohormone production $[18,19]$. Among these soil born PGPB, some bacterial candidates have played an influential role in releasing various essential macro and micronutrients from the minerals in large enough quantities to sustain crop growth. Potassium solubilizing bacteria is one such group of mineral solubilizers that have been reported to release $\mathrm{K}$ in its available form from K-bearing minerals such as illite, mica, feldspars, etc., by excreting various organic acids that directly dissolve minerals or chelate silicon ions to release K [20-25]. An array of such bacteria, such as Bacillus sp. [2,14], Pseudomonas sp. [25], Paenibacillus sp. [26], Burkholderia sp. [21], Streptomyces sp. [27] have been documented to show K solubilization potential. Solubilization of $\mathrm{K}$ by the bacterial isolates is influenced by factors such as soil $\mathrm{pH}$, the solubility index of a mineral, temperature, moisture, and above all, the nativity of the bacteria. It has been observed that a microorganism from a particular agro-ecosystem may not express its full mineral solubilization potential when applied in an environment different from its original place of isolation. The performance of region-specific microorganisms has always been found outstanding [28].

The Kashmir and Ladakh regions of Jammu and Kashmir State are unique in that they experience more diverse climatic conditions than other states in India. The soils of the extreme northern areas of this Himalayan state harbor cold-tolerant mineral solubilizing microbes, which can be applied for improving the nutrient availability for growing crops on an eco-friendly and long-term basis. The microbes that have attained the adaption of surviving and functioning under cold climatic conditions are referred to as cold-tolerant; 
such microbes isolated from the Arctic and Himalayas were found to exhibit plant growthpromoting (PGP) activity at a temperature range of $4-25^{\circ} \mathrm{C}[29,30]$. Therefore, the present study was undertaken to screen potent cold-tolerant $\mathrm{K}$ solubilizing bacteria for application in crop fields in the temperate and cold desert regions.

\section{Materials and Methods}

\subsection{Location Description and Collection of Soil Sample}

The study area from which the K solubilizing bacteria have been isolated includes the Ladakh region and Kashmir valley of Jammu and Kashmir State, India. The Ladakh region, known as the cold desert, is located at altitudes of 2676 to $3500 \mathrm{~m}$, with a mean annual temperature of $8.6^{\circ} \mathrm{C}$, and receives the scant annual rainfall of $102 \mathrm{~mm}$ to $318 \mathrm{~mm}$. The soils are by and large sandy in texture with low organic matter content. Soil reaction is generally alkaline. Drass, a subdivision of the Ladakh region, is recognized as being the second coldest place globally, with mean annual winter and summer temperatures of $-12{ }^{\circ} \mathrm{C}$ and $23{ }^{\circ} \mathrm{C}$, respectively [31]. Kashmir Valley is a temperate region located at an altitude of above $1850 \mathrm{~m}$.

The soil adhered to the roots of crop plants like maize, oats, wheat, barley, potato, brinjal, tomato, apple, pear, walnut, and almond were collected in sterile polythene bags. Samples from pastures, forests, and glacier sites were also collected from the study area between 2015-2016. The upper surface layer was scrapped, and the rhizosphere soil samples up to the depth of $10 \mathrm{~cm}$ were collected. All samples were collected in sterilized zip-locked polybags and stockpiled in an ice chest during transport, preserved at $4{ }^{\circ} \mathrm{C}$ under refrigeration conditions in the laboratory, and utilized within 12-24 $\mathrm{h}$ after collection for further analysis.

\subsection{Isolation of K Solubilizing Rhizobacteria}

K solubilizing bacteria were isolated on Aleksandrov's medium containing $(\mathrm{g} / \mathrm{L})$ $5.0 \mathrm{~g} / \mathrm{L}$ glucose, $0.005 \mathrm{~g} / \mathrm{L}$ magnesium sulphate, $0.1 \mathrm{~g} / \mathrm{L}$ ferric chloride, $2.0 \mathrm{~g} / \mathrm{L}$ calcium carbonate, $2.0 \mathrm{~g} / \mathrm{L} \mathrm{K}$ mineral (mica), $2.0 \mathrm{~g} / \mathrm{L}$ calcium phosphate, $20.0 \mathrm{~g} / \mathrm{L}$ agar, and $1000 \mathrm{~mL}$ distilled water, following modified standard methodology [32]. Serial dilution and pour plating technique was used for isolating the $\mathrm{K}$ solubilizing bacteria, followed by incubating the plates at $10 \pm 0.2{ }^{\circ} \mathrm{C}$ in an inverted position for five days. The colonies that formed hollow zones on the mica amended medium were considered positive for mineral $\mathrm{K}$ solubilization and were further purified by repeated streaking on Aleksandrov's medium, then preserved at $4{ }^{\circ} \mathrm{C}$ for further studies [2]. The standard strain Bacillus mucilaginosus used as a control was obtained from the Department of Soil Science and Agricultural Chemistry, VN Marathwada Agriculture University, Parbhani, Maharashtra, India.

\subsection{Screening of K Solubilizing Rhizobacteria}

\subsubsection{Qualitative Screening for K Solubilization Potential}

K solubilization potential of rhizobacterial isolates was qualitatively determined by spot inoculating pure bacterial colonies on Aleksandrov's medium plates containing mica as insoluble $\mathrm{K}$ source and incubating for 20 days. The $\mathrm{K}$ solubilization potential was assessed by measuring the diameter of hollow zones formed on the medium. The colony diameter was also measured to work out the solubilization efficiency by using the following formula [33].

\subsubsection{Quantitative Screening for K Solubilization Potential}

To analyze the K solubilization of isolates, a loopful of $24 \mathrm{~h}$ old culture of each rhizobacterial cultures were inoculated into $25 \mathrm{~mL}$ of sterilized Aleksandrov's broth in $50 \mathrm{~mL}$ flasks and incubated at $0,1,3,5,7,15$, and $20{ }^{\circ} \mathrm{C}$ for 5,10 and 20 days on an incubating shaker at $100 \mathrm{rpm}$. Flasks inoculated with Bacillus mucilaginosus were used as controls. The incubated bacterial suspension was centrifuged at $8000 \times g$ after different time intervals for $10 \mathrm{~min}$ to separate supernatant from cell mass, and insoluble K. Supernatant 
$1 \mathrm{~mL}$ was collected in a volumetric flask of $50 \mathrm{~mL}$ capacity, and volume was made up to $50 \mathrm{~mL}$ with $\mathrm{dH}_{2} \mathrm{O}$ and thoroughly mixed. This solution was fed to a flame photometer to assess the K content [34]. Working standards of 0.0004, 0.0009, 0.001, 0.002 and $0.0024 \mathrm{~g}$ $\mathrm{KCl}$ solution were utilized to prepare the standard curve and were used for estimating the quantity of $\mathrm{K}$ solubilized by the bacterial isolates through the following equation

$$
A=m c
$$

where,

$$
\begin{aligned}
& A=\text { absorbance of the solution } \\
& m=\text { slope of curve, and } \\
& c=\text { concentration of unknown solution }
\end{aligned}
$$

\subsection{Production of Plant Growth-Promoting Characteristics \\ 2.4.1. Hydrogen Cyanide}

Qualitative production of hydrogen cyanide was assessed by streaking KSB isolates on King's B medium augmented with $4.4 \mathrm{~g} / \mathrm{L}$ glycine. Sterilized filter paper soaked in picric acid solution (2.5 g of picric acid; $12.5 \mathrm{~g}$ of $\mathrm{Na}_{2} \mathrm{CO}_{3}, 1 \mathrm{~L}$ of $\mathrm{dH}_{2} \mathrm{O}$ ) was positioned inside the upper lid of the petri dish. The dishes were sealed adequately with the parafilm and incubated at $20 \pm 1{ }^{\circ} \mathrm{C}$ for $48 \mathrm{~h}$. Color change from yellow to different brownish shades was treated as a positive result for hydrogen cyanide production. Based on color change, concentration from yellow to light brown or reddish-brown was considered as weak $(+)$, moderate $(++)$, or strong $(+++)$, accordingly [35].

\subsubsection{Ammonia Production}

All KSB strains were incubated in peptone water $(100 \mathrm{~mL})$ for $4-5$ days at $20 \pm 2{ }^{\circ} \mathrm{C}$ for the determination of ammonia production [36]. After incubation, $1 \mathrm{~mL}$ of Nessler's reagent was supplemented in each tube and the appearance of brown to yellow colour indicated the ammonia production.

\subsubsection{Indole Acetic Acid (IAA) Production}

IAA production was tested according to the modified standard protocol [37]. Fresh cultures of all KSB isolates were inoculated in $5 \mathrm{~mL}$ respective broth tubes and incubated at a specified temperature and time. After incubation, these cultures were centrifuged at $10,000 \times g$ for $5 \mathrm{~min}$. To $1 \mathrm{~mL}$ of supernatant, $4 \mathrm{~mL}$ IAA reagent (containing $0.5 \mathrm{M}$ $\mathrm{FeCl}_{3}, 1 \mathrm{~mL}$, concentrated $\mathrm{H}_{2} \mathrm{SO}_{4} 30 \mathrm{~mL}$ and distilled water $50 \mathrm{~mL}$ ) was added, and a final volume of $5 \mathrm{~mL}$ was produced, followed by incubation at $20 \pm 2{ }^{\circ} \mathrm{C}$ for $30 \mathrm{~min}$. The development of a pink color was considered to be positive for IAA production. Using a UV spectrophotometer, absorbance at $530 \mathrm{~nm}$ was taken to determine the concentration of IAA in all culture tubes with the help a standard curve prepared with different concentrations of analytical grade IAA.

\subsubsection{Protease Activity}

The overnight grown bacterial cultures in protease production media were centrifuged at $10,000 \times g$ for $10 \mathrm{~min}$ at $4{ }^{\circ} \mathrm{C}$ to collect the supernatant of crude extracellular enzyme, followed by determination of protease activity according to the modified protocol [38]. The reaction mixture contained casein $(0.6 \% w / v)$ in $200 \mu \mathrm{L}(0.05 \mathrm{M})$ Tris- $\mathrm{HCl}$ buffer (pH 7.0) and $100 \mu \mathrm{L}$ enzyme. For $30 \mathrm{~min}$ the reaction mixture was incubated at $20^{\circ} \mathrm{C}$ followed by the addition of $300 \mu \mathrm{L}$ of $10 \%(w / v)$ trichloroacetic acid (TCA) to stop the reaction. Afterwards, the solution was centrifuged at $16,128 \times g$ and $4{ }^{\circ} \mathrm{C}$ for $10 \mathrm{~min}$, and supernatants $(500 \mu \mathrm{L})$ were taken by pipetting into separate tubes to which $\mathrm{Na}_{2} \mathrm{CO}_{3}(0.4 \mathrm{M}, 2 \mathrm{~mL})$ and FolinCio-Calteu reagent $(1 \mathrm{~N}, 250 \mu \mathrm{L})$ were added. The solutions were incubated at $30{ }^{\circ} \mathrm{C}$ for $25 \mathrm{~min}$ and absorbance was measured at $660 \mathrm{~nm}$. The protease activity was expressed in $\mu \mathrm{g}$ of tyrosine produced by $1 \mathrm{~mL}$ of enzyme in $60 \mathrm{~min}$ at $20^{\circ} \mathrm{C}$ on tyrosine equivalent. One 
unit of protease activity was defined as the increase of 0.1-unit optic density at a one $\mathrm{h}$ incubation period.

\subsubsection{Chitinase Production}

The chitinase activity of the bacterial isolates was determined using the modified protocol of [39]. The reaction mixture, containing $2.5 \mathrm{~mL}$ of $1 \%$ colloidal chitin dissolved in $2.5 \mathrm{~mL}$ of phosphate buffer solution and $0.5 \mathrm{~mL}$ crude enzyme, was taken in flasks and incubated at $20^{\circ} \mathrm{C}$ for $1 \mathrm{~h}$. The reaction was stopped by the addition of dinitrosalicylic (DNS) acid, followed by incubation within a boiling water bath for $10 \mathrm{~min}$. The solution was subjected to centrifugation to collect the supernatant, and the amount of sugar released was estimated at $540 \mathrm{~nm}$ (UV spectrophotometer). Under standard assay conditions, one unit of chitinase activity (U) was defined as the quantity of enzyme that yields $1 \mu \mathrm{M}$ of reducing sugar/minute.

\subsubsection{Cellulase Activity}

Cellulase activity of the bacterial strains was measured by the following method [40]. The reaction mixtures containing $1.8 \mathrm{~mL}$ of $0.5 \%$ carboxymethyl cellulose (CMC) were added to $50 \mathrm{mM}$ sodium phosphate buffer $(\mathrm{pH} 7)$ and $0.2 \mathrm{~mL}$ of crude enzyme in screw capped tubes, and were incubated at $20^{\circ} \mathrm{C}$ in a water bath for $30 \mathrm{~min}$. Then $3 \mathrm{~mL}$ of DNS reagent was added to each tube to terminate the reaction and centrifuged to estimate the amount of sugars liberated by taking absorbance at $540 \mathrm{~nm}$. Cellulase production was assessed using a glucose calibration curve. One unit (U) of enzyme activity is the amount of enzyme needed under standard assay conditions to release $1 \mu \mathrm{M}$ of glucose per minute.

\subsection{Morphological and Biochemical Characteristics}

The best KSB isolate was examined for colony morphology, cell shape, and gram reaction, and biochemical characterization according to Bergey's Manual of Determinative Bacteriology.

\subsection{Molecular Characterization and Phylogenetic Analysis of KSB}

By using the colony-polymerase chain reaction (PCR) method, the molecular characterization of the selected bacterial isolate was carried out [41]. The universal bacterial primers 27F (5'AGAGTTTGATCCTGGCTCAG3') and 1492R (5'-GGTTACCTTGTTACGACTT-3') were used for all bacterial isolates [32]. The PCR reaction was carried out in a final volume of $50 \mu \mathrm{L}$ containing $3 \mu \mathrm{L}$ of template DNA, $2 \mu \mathrm{L}$ of each forward and reverse primer, $0.5 \mu \mathrm{L}$ of Taq DNA polymerase, $2 \mu \mathrm{L}$ of dNTP mixture, $5 \mu \mathrm{L}$ of buffer solution (with $\mathrm{MgCl}_{2}$ ), and $37.5 \mu \mathrm{L}$ of de-ionized water. Amplification was performed as follows: 30 cycles of $95{ }^{\circ} \mathrm{C}$ for $3 \mathrm{~min}, 94{ }^{\circ} \mathrm{C}$ for $30 \mathrm{~s}, 55^{\circ} \mathrm{C}$ for $30 \mathrm{~s}, 72{ }^{\circ} \mathrm{C}$ for $50 \mathrm{~s}, 72{ }^{\circ} \mathrm{C}$ for $8 \mathrm{~min}$. PCR products were sequenced at AgriGenome Lab, Pvt. Ltd., $\mathrm{C}^{\circ} \mathrm{Chi}$, Kerala and the unknown sequence was then identified using the maximum aligned $16 \mathrm{~S}$ rDNA sequences available in the Gen-Bank of NCBI through BLAST. The phylogenetic tree was built by using the neighbor-joining method.

\subsection{Statistical Analysis}

All experiments were performed in five replicates and the results were stated as means for each sample, including the control group (standard group). The SPSS 16.0 statistical package was used for performing all statistical analyses. One-way analysis of variance (ANOVA) and post hoc analysis (Duncan's Multiple Range Test) were performed to compare mean values of the isolates and the standard $(p<0.05)$.

\section{Results and Discussion}

\subsection{Isolation of K Solubilizing Rhizobacteria}

From the different soil samples collected from the Ladakh region and Kashmir valley, 110 morphologically different bacteria were isolated. Among these 110 bacterial isolates, 
only 13 isolates showed K solubilizing ability by forming a halo zone on Aleksandrov's agar media (Figure 1). In a previous study, the isolation of $15 \mathrm{~K}$-solubilizing rhizobacteria (KSR) from soil samples collected from hilly areas depending on their capability to solubilize mica as insoluble K source was reported [2]. Studies have also shown that different species of KSB exist in the soil and play a vital role in the K cycle [42,43]. Potassium solubilizing bacteria (KSB) are involved in the natural potassium cycle, and therefore, the presence of KSB in the soil makes potassium available for uptake by plants [22,44]. However, few studies on KSB isolation from the cold regions are available in the literature, and the isolates of the present study were cold tolerant for their adaptation of surviving and functioning under cold climatic conditions.

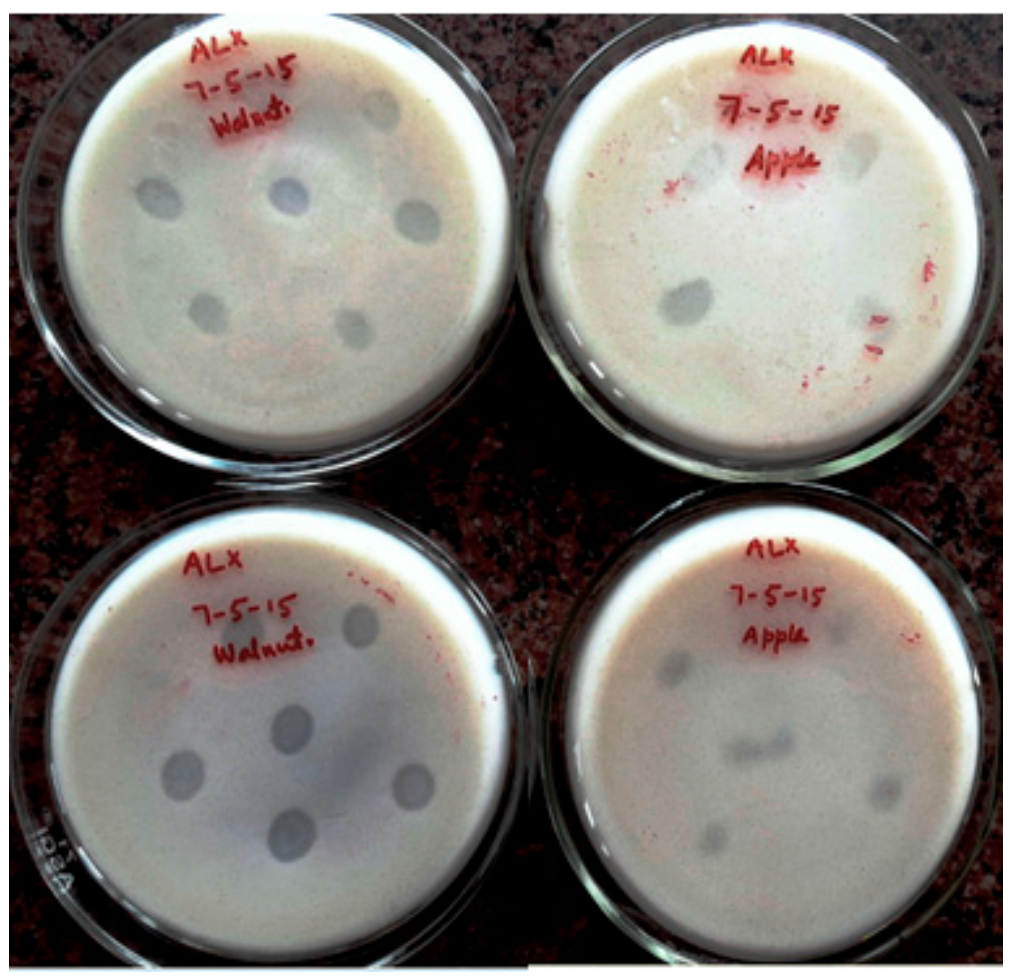

Figure 1. KSB showing solubilization on Aleksandrov's agar media at $10{ }^{\circ} \mathrm{C}$.

\subsection{Qualitative Screening for K Solubilization Potential}

All thirteen strains were evaluated for the potential qualitative K solubilization under in-vitro conditions. All the strains produced clear solubilization halo zones of different diameters on Aleksandrov's agar medium, ranging from 3.10-5.27 cm after $48 \mathrm{~h}$ of incubation at $20^{\circ} \mathrm{C}$ (Table 1$)$. The results reveal that out of thirteen, only seven isolates showed significantly $(p<0.05)$ higher solubilization efficiency in comparison to the standard isolate (Bacillus mucilaginosus) $(169.79 \%)$. However, the highest significant $(p<0.05)$ solubilization efficiency was displayed by isolate KSB (Grz) (462.28\%). Solubilization of mineral $\mathrm{K}$ compounds by the abundant soil microorganisms is a common phenomenon through the secretion of organic acids and enzymes, and the production of capsular polysaccharides [21,43]. Other investigations have reported that out of 12 psychrotrophic PGPR bacterial species screened qualitatively for $\mathrm{K}$ solubilization, the isolate with strain no. IARI-AR26 displayed the largest halo zone radius $(5.8 \mathrm{~mm})$ [42]. Moreover, 11 rhizospheric potassium solubilizing bacteria were screened, and the best isolate, UPS1C1, had a maximum zone growth ratio of 5.0 [42]. 
Table 1. K solubilization efficiency of cold-tolerant bacterial isolates at $20^{\circ} \mathrm{C}$ after $48 \mathrm{~h}$.

\begin{tabular}{cccc}
\hline Isolates & $\begin{array}{c}\text { K Solubilization } \\
\text { Hallow } \mathbf{( c m )}\end{array}$ & $\begin{array}{c}\text { Colony Diameter } \\
(\mathbf{c m})\end{array}$ & $\begin{array}{c}\text { Solubilization } \\
\text { Efficiency (\%) }\end{array}$ \\
\hline Bacillus mucilaginosus * & 3.26 & 1.92 & $169.79^{\mathrm{h}}$ \\
KSB(Smg) & 3.37 & 2.82 & $119.50^{1}$ \\
KSB (Drs) & 4.11 & 1.89 & $217.46^{\mathrm{e}}$ \\
KSBM & 3.10 & 1.98 & $156.56^{\mathrm{i}}$ \\
KSB(Gmr) & 3.47 & 2.61 & $132.95^{\mathrm{k}}$ \\
KSB(Mng) & 4.72 & 1.56 & $302.56^{\mathrm{c}}$ \\
KSB(Pd) & 3.25 & 2.97 & $109.42^{\mathrm{m}}$ \\
KSB(Sls) & 3.17 & 3.12 & $101.60^{\mathrm{n}}$ \\
KSB(Trs) & 3.97 & 2.10 & $189.04^{\mathrm{f}}$ \\
KSB(Kgl) & 4.38 & 1.77 & $247.45^{\mathrm{d}}$ \\
KSB(Grz) & 5.27 & 1.14 & $462.28^{\mathrm{a}}$ \\
KSB(Phg) & 3.84 & 2.18 & $176.14^{\mathrm{g}}$ \\
KSB(Glm) & 4.97 & 1.26 & $394.44^{\mathrm{b}}$ \\
KSB(Afr) & 3.61 & 2.54 & $142.12^{\mathrm{j}}$ \\
\hline
\end{tabular}

${ }^{*}$ Used as standard. Different letters on the mean values represent significantly $(p<0.05)$ different values according to Duncan's Multiple Range Test (DMRT).

\subsection{Quantitative Screening for K Solubilization Potential}

The quantitative K solubilization by all 13 KSB isolates was assessed by incubating them at different incubation periods viz. 5, 10, and 20 days, at incubation temperatures of $0{ }^{\circ} \mathrm{C}, 1{ }^{\circ} \mathrm{C}, 3{ }^{\circ} \mathrm{C}, 5^{\circ} \mathrm{C}, 7{ }^{\circ} \mathrm{C}, 15^{\circ} \mathrm{C}$, and $20^{\circ} \mathrm{C}$ as shown in Tables $2-4$, respectively.

The results revealed that the standard isolate showed solubilization activity only at $7{ }^{\circ} \mathrm{C}, 15{ }^{\circ} \mathrm{C}$, and $20^{\circ} \mathrm{C}$, by producing $0.89,2.29$, and $4.31 \mu \mathrm{g} \mathrm{K} / \mathrm{mL}$ broth, respectively. All the isolates except KSB (Sls) and KSB (Trs) produced a significantly $(p<0.05)$ higher quantity of $\mathrm{K}$ compared to standard at an incubation temperature of $20{ }^{\circ} \mathrm{C}$. However, the maximum quantity (10.19 $\mu \mathrm{g} \mathrm{K} / \mathrm{mL}$ broth) of $\mathrm{K}$ was solubilized by isolate $\mathrm{KSB}$ (Grz), which is $136.4 \%$ more than the standard. Mineral $\mathrm{K}$ solubilization by isolates even below sub-optimal temperature conditions supports the cold-tolerant nature of these isolates (Table 2).

Table 2. Quantitative K solubilization ( $\mu \mathrm{g} \mathrm{K} / \mathrm{mL}$ broth) potential of cold-tolerant bacterial isolates at different temperatures after 5 days of incubation.

\begin{tabular}{|c|c|c|c|c|c|c|c|}
\hline \multirow{2}{*}{ Isolates } & \multicolumn{7}{|c|}{ Incubation Temperature } \\
\hline & $0^{\circ} \mathrm{C}$ & $1^{\circ} \mathrm{C}$ & $3^{\circ} \mathrm{C}$ & $5^{\circ} \mathrm{C}$ & $7^{\circ} \mathrm{C}$ & $15^{\circ} \mathrm{C}$ & $20{ }^{\circ} \mathrm{C}$ \\
\hline Bacillus mucilaginosus & $0.00^{\mathrm{i}}$ & $0.00^{\mathrm{n}}$ & $0.00^{\mathrm{h}}$ & $0.00^{1}$ & $0.89^{n}$ & $2.29^{\mathrm{i}}$ & $4.31^{1}$ \\
\hline KSB(Smg) & $1.15^{\mathrm{c}}$ & $1.53^{\mathrm{f}}$ & $1.97 \mathrm{bcd}$ & $2.35^{\mathrm{f}}$ & $3.18^{\mathrm{f}}$ & $5.11^{b c d}$ & $7.41^{\mathrm{b}}$ \\
\hline KSB(Drs) & $0.89 \mathrm{~g}$ & $1.618^{\mathrm{d}}$ & $2.01 \mathrm{abc}$ & $2.50^{\mathrm{e}}$ & $3.85^{b}$ & 4.93 cde & $5.55^{\mathrm{i}}$ \\
\hline KSBM & $1.14^{\mathrm{cd}}$ & $1.48^{\mathrm{g}}$ & $1.97 \mathrm{bcd}$ & $2.06^{\mathrm{h}}$ & $2.80^{\mathrm{i}}$ & $3.94 \mathrm{~g}$ & $4.90^{\mathrm{k}}$ \\
\hline $\mathrm{KSB}(\mathrm{Gmr})$ & $1.33^{b}$ & $1.67^{\mathrm{c}}$ & $2.18^{a b}$ & $3.10^{\mathrm{b}}$ & $3.55^{c}$ & 4.70 de & $6.51^{\mathrm{e}}$ \\
\hline KSB(Mng) & $1.09^{\mathrm{d}}$ & $1.15^{\mathrm{k}}$ & $2.00^{\mathrm{e}}$ & $2.70^{\mathrm{d}}$ & $3.21^{\mathrm{e}}$ & $5.45^{b}$ & $6.55^{\mathrm{d}}$ \\
\hline $\mathrm{KSB}(\mathrm{Pd})$ & $1.10^{\mathrm{cd}}$ & $1.45^{\mathrm{h}}$ & $1.75 \mathrm{de}$ & $2.11^{\mathrm{g}}$ & $3.09 \mathrm{~g}$ & $5.23 \mathrm{bc}$ & $7.12^{\mathrm{c}}$ \\
\hline $\mathrm{KSB}(\mathrm{Sls})$ & $0.73^{\mathrm{h}}$ & $0.98^{1}$ & $1.26^{\mathrm{f}}$ & $1.73^{j}$ & $2.07^{1}$ & $3.87 \mathrm{~g}$ & $4.25^{\mathrm{m}}$ \\
\hline KSB(Trs) & $0.33^{j}$ & $0.59 \mathrm{~m}$ & $0.91^{\mathrm{g}}$ & $1.37^{\mathrm{k}}$ & $1.49^{\mathrm{m}}$ & $2.13^{i}$ & $4.11^{\mathrm{n}}$ \\
\hline $\mathrm{KSB}(\mathrm{Kgl})$ & $1.30^{b}$ & $1.57^{\mathrm{e}}$ & $1.83^{\text {cde }}$ & $2.05^{\mathrm{h}}$ & $2.39^{k}$ & $4.19 \mathrm{fg}$ & $5.67^{\mathrm{h}}$ \\
\hline KSB(Grz) & $1.55^{\mathrm{a}}$ & $1.90^{\mathrm{a}}$ & $2.29^{a}$ & $3.45^{\mathrm{a}}$ & $4.20^{\mathrm{a}}$ & $7.11^{\mathrm{a}}$ & $10.19^{\mathrm{a}}(136.4 \%)$ \\
\hline KSB(Phg) & $1.00^{\mathrm{e}}$ & $1.26^{\mathrm{j}}$ & $1.58^{\mathrm{e}}$ & $2.03^{\mathrm{i}}$ & $2.91^{\mathrm{h}}$ & 4.55 ef & $6.15^{f}$ \\
\hline $\mathrm{KSB}(\mathrm{Glm})$ & $1.15^{\mathrm{c}}$ & $1.69^{b}$ & $2.13^{a b}$ & $2.75^{c}$ & $3.28^{d}$ & 5.24 cde & $6.13^{g}$ \\
\hline $\mathrm{KSB}(\mathrm{Afr})$ & $0.95^{\mathrm{f}}$ & $1.36^{\mathrm{i}}$ & $1.72 \mathrm{de}$ & $2.033^{\mathrm{i}}$ & $2.46^{j}$ & $3.89^{h}$ & $5.31^{\mathrm{j}}$ \\
\hline
\end{tabular}

Different letters on the mean values represent significantly $(p<0.05)$ different values according to Duncan's Multiple Range Test (DMRT). 
Table 3. Quantitative K solubilization ( $\mu \mathrm{g} \mathrm{K} / \mathrm{mL}$ broth) potential of cold-tolerant bacterial isolates at different temperatures after 10 days of incubation.

\begin{tabular}{|c|c|c|c|c|c|c|c|}
\hline \multirow{2}{*}{ Isolates } & \multicolumn{7}{|c|}{ Incubation Temperature } \\
\hline & $0^{\circ} \mathrm{C}$ & $1^{\circ} \mathrm{C}$ & $3{ }^{\circ} \mathrm{C}$ & $5{ }^{\circ} \mathrm{C}$ & $7^{\circ} \mathrm{C}$ & $15^{\circ} \mathrm{C}$ & $20{ }^{\circ} \mathrm{C}$ \\
\hline Bacillus mucilaginosus & $0.00^{n}$ & $0.00^{\mathrm{n}}$ & $0.00^{n}$ & $0.03^{n}$ & $1.64^{\mathrm{n}}$ & $4.9^{n}$ & $8.13^{j}$ \\
\hline $\mathrm{KSB}(\mathrm{Smg})$ & $1.79^{b}$ & $3.31^{\mathrm{b}}$ & $4.27^{\mathrm{a}}$ & $3.09^{\mathrm{a}}$ & $5.03^{\mathrm{d}}$ & $8.43^{b}$ & $11.57^{\mathrm{b}}$ \\
\hline KSB(Drs) & $1.50^{\mathrm{h}}$ & $2.25 \mathrm{~g}$ & $2.80^{g}$ & $3.30 \mathrm{~g}$ & $5.09^{c}$ & $7.89^{\mathrm{f}}$ & $9.29^{\mathrm{h}}$ \\
\hline KSBM & $1.22^{1}$ & $2.73^{\mathrm{d}}$ & $3.51^{\mathrm{d}}$ & $3.95^{\mathrm{d}}$ & $4.35^{\mathrm{f}}$ & $5.48^{\mathrm{m}}$ & $7.91^{n}$ \\
\hline $\mathrm{KSB}(\mathrm{Gmr})$ & $1.75^{\mathrm{d}}$ & $3.21^{c}$ & $4.03^{c}$ & $4.75^{\mathrm{c}}$ & $5.11^{\mathrm{b}}$ & $8.13^{c}$ & $11.17^{\mathrm{c}}$ \\
\hline KSB(Mng) & $1.55^{f}$ & $2.67^{\mathrm{e}}$ & $2.91^{\mathrm{f}}$ & $3.45^{f}$ & $4.33^{\mathrm{g}}$ & $7.85^{g}$ & $10.06^{\mathrm{f}}$ \\
\hline $\mathrm{KSB}(\mathrm{Pd})$ & $1.39^{\mathrm{j}}$ & $1.87^{\mathrm{k}}$ & $2.39^{\mathrm{i}}$ & $3.11^{\mathrm{i}}$ & $3.89^{\mathrm{j}}$ & $6.31^{\mathrm{i}}$ & $8.76^{\mathrm{i}}$ \\
\hline $\mathrm{KSB}(\mathrm{Sls})$ & $1.30^{\mathrm{k}}$ & $1.67^{1}$ & $2.00^{1}$ & $2.39^{1}$ & $3.19^{1}$ & $5.88^{\mathrm{j}}$ & $8.00^{1}$ \\
\hline KSB(Trs) & $1.15^{\mathrm{m}}$ & $1.43^{\mathrm{m}}$ & $1.89^{\mathrm{m}}$ & $2.29 \mathrm{~m}$ & $3.17^{\mathrm{m}}$ & $5.76^{1}$ & $7.98^{\mathrm{m}}$ \\
\hline $\mathrm{KSB}(\mathrm{Kgl})$ & $1.77^{\mathrm{c}}$ & $2.53^{f}$ & $3.19^{\mathrm{e}}$ & $3.90^{\mathrm{e}}$ & $4.49^{\mathrm{e}}$ & $8.11^{\mathrm{d}}$ & $11.00^{\mathrm{d}}$ \\
\hline KSB(Grz) & $2.15^{\mathrm{a}}$ & $3.67^{\mathrm{a}}$ & $4.10^{b}$ & $4.79^{b}$ & $5.29^{a}$ & $9.20^{\mathrm{a}}$ & $13.33^{\mathrm{a}}(63.9 \%)$ \\
\hline KSB(Phg) & $1.50 \mathrm{~g}$ & $1.89^{\mathrm{i}}$ & $2.33^{\mathrm{j}}$ & $3.01^{\mathrm{j}}$ & $3.99^{\mathrm{i}}$ & $7.67^{\mathrm{h}}$ & $10.01 \mathrm{~g}$ \\
\hline $\mathrm{KSB}(\mathrm{Glm})$ & $1.61^{\mathrm{e}}$ & $2.037^{\mathrm{h}}$ & $2.58^{\mathrm{h}}$ & $3.27^{\mathrm{h}}$ & $4.11^{\mathrm{h}}$ & $8.01^{\mathrm{e}}$ & $10.66^{\mathrm{e}}$ \\
\hline $\mathrm{KSB}(\mathrm{Afr})$ & $1.43^{\mathrm{i}}$ & $1.87^{\mathrm{j}}$ & $2.29^{k}$ & $2.60^{\mathrm{k}}$ & $3.21^{\mathrm{k}}$ & $5.77^{\mathrm{k}}$ & $8.11^{\mathrm{k}}$ \\
\hline
\end{tabular}

Different letters on the mean values represent significantly $(p<0.05)$ different values according to Duncan's Multiple Range Test (DMRT).

Table 4. Quantitative K solubilization ( $\mu \mathrm{g} \mathrm{K} / \mathrm{mL}$ broth) potential of cold-tolerant bacterial isolates at different temperatures after 20 days of incubation.

\begin{tabular}{|c|c|c|c|c|c|c|c|}
\hline \multirow{2}{*}{ Isolates } & \multicolumn{7}{|c|}{ Incubation Temperature } \\
\hline & $0^{\circ} \mathrm{C}$ & $1^{\circ} \mathrm{C}$ & $3^{\circ} \mathrm{C}$ & $5^{\circ} \mathrm{C}$ & $7^{\circ} \mathrm{C}$ & $15^{\circ} \mathrm{C}$ & $20{ }^{\circ} \mathrm{C}$ \\
\hline Bacillus mucilaginosus & $0.00^{1}$ & $0.00^{n}$ & $0.00^{\mathrm{m}}$ & $0.04^{n}$ & $2.97^{n}$ & $10.76^{\mathrm{m}}$ & $15.33^{f}$ \\
\hline $\mathrm{KSB}(\mathrm{Smg})$ & $2.11^{b}$ & $5.21^{\mathrm{b}}$ & $6.89^{b}$ & $8.41^{b}$ & $10.58^{c}$ & $19.73^{b}$ & $19.72^{b}$ \\
\hline KSB(Drs) & $1.90^{\mathrm{f}}$ & $4.91^{\mathrm{e}}$ & $6.10^{\mathrm{e}}$ & $7.01^{\mathrm{e}}$ & $9.13^{\mathrm{e}}$ & $17.30^{\mathrm{e}}$ & $17.31^{\mathrm{e}}$ \\
\hline KSBM & $1.80^{\mathrm{h}}$ & $4.10^{\mathrm{f}}$ & $5.92^{f}$ & $6.97^{\mathrm{f}}$ & $8.23^{f}$ & $12.10^{\mathrm{i}}$ & $14.90^{g}$ \\
\hline $\mathrm{KSB}(\mathrm{Gmr})$ & $2.05^{c}$ & $5.04^{\mathrm{c}}$ & $6.67^{c}$ & $7.25^{c}$ & $10.27^{\mathrm{d}}$ & $18.34^{\mathrm{c}}$ & $18.34^{\mathrm{c}}$ \\
\hline KSB(Mng) & $1.95^{\mathrm{d}}$ & $4.97^{\mathrm{d}}$ & $6.43^{\mathrm{d}}$ & $7.11^{\mathrm{d}}$ & $10.89^{b}$ & $17.83^{\mathrm{d}}$ & $17.84^{\mathrm{d}}$ \\
\hline $\mathrm{KSB}(\mathrm{Pd})$ & $1.84^{\mathrm{h}}$ & $3.70^{g}$ & $5.05^{\mathrm{i}}$ & $6.08^{g}$ & $6.78^{\mathrm{g}}$ & $13.09 \mathrm{~g}$ & $13.10^{\mathrm{i}}$ \\
\hline $\mathrm{KSB}(\mathrm{Sls})$ & $1.67^{\mathrm{j}}$ & $2.78^{1}$ & $4.09^{k}$ & $4.90^{1}$ & $5.55^{1}$ & $10.97^{k}$ & $10.97 \mathrm{~m}$ \\
\hline KSB(Trs) & $1.50^{\mathrm{k}}$ & $2.47^{\mathrm{m}}$ & $3.85^{1}$ & $4.44^{\mathrm{m}}$ & $5.13^{\mathrm{m}}$ & $9.50^{1}$ & $9.80^{\mathrm{n}}$ \\
\hline $\mathrm{KSB}(\mathrm{Kgl})$ & $1.93^{\mathrm{e}}$ & $3.57^{\mathrm{i}}$ & $5.19^{g}$ & $5.90^{\mathrm{h}}$ & $6.43^{\mathrm{h}}$ & $12.07^{\mathrm{j}}$ & $12.10^{\mathrm{k}}$ \\
\hline KSB(Grz) & $3.17^{\mathrm{a}}$ & $6.35^{\mathrm{a}}$ & $8.88^{a}$ & $10.00^{a}$ & $12.32^{\mathrm{a}}$ & $23.35^{a}$ & $23.38^{\mathrm{a}}(52.5 \%)$ \\
\hline KSB(Phg) & $1.79^{\mathrm{i}}$ & $3.39^{k}$ & $5.00^{j}$ & $5.817^{\mathrm{j}}$ & $6.19^{j}$ & $12.00^{\mathrm{j}}$ & $12.00^{1}$ \\
\hline $\mathrm{KSB}(\mathrm{Glm})$ & $1.87^{\mathrm{g}}$ & $3.59^{\mathrm{h}}$ & $5.11^{\mathrm{h}}$ & $5.87^{\mathrm{i}}$ & $6.40^{\mathrm{i}}$ & $13.23^{f}$ & $13.24^{\mathrm{h}}$ \\
\hline KSB(Afr) & $1.80^{\mathrm{h}}$ & $3.49^{j}$ & $5.01^{\mathrm{i}}$ & $5.70^{\mathrm{k}}$ & $6.013^{k}$ & $12.87^{\mathrm{h}}$ & $12.89^{\mathrm{j}}$ \\
\hline
\end{tabular}

Different letters on the mean values represent significantly $(p<0.05)$ different values according to Duncan's Multiple Range Test (DMRT).

$\mathrm{K}$ solubilization by different bacterial isolates after ten days of incubation time at $0{ }^{\circ} \mathrm{C}, 1{ }^{\circ} \mathrm{C}, 3{ }^{\circ} \mathrm{C}, 5^{\circ} \mathrm{C}, 7{ }^{\circ} \mathrm{C}, 15^{\circ} \mathrm{C}$, and $20^{\circ} \mathrm{C}$ incubation temperatures, exhibited that the standard (Bacillus mucilaginosus) did not solubilize any quantity of $\mathrm{K}$ at $0{ }^{\circ} \mathrm{C}, 1{ }^{\circ} \mathrm{C}$ and $3{ }^{\circ} \mathrm{C}$ (Table 3). However, at $5{ }^{\circ} \mathrm{C}, 7{ }^{\circ} \mathrm{C}, 15{ }^{\circ} \mathrm{C}$ and $20^{\circ} \mathrm{C}$, it solubilized $0.03,1.64$, 4.9 and $8.13 \mu \mathrm{g} \mathrm{K} / \mathrm{mL}$ broth, respectively. A total of 9/13 isolates, including $\mathrm{KSB}(\mathrm{Smg})$, $\mathrm{KSB}(\mathrm{Drs}), \mathrm{KSB}(\mathrm{Gmr}), \mathrm{KSB}(\mathrm{Mng}), \mathrm{KSB}(\mathrm{Pd}), \mathrm{KSB}(\mathrm{Kgl}), \mathrm{KSB}(\mathrm{Grz}), \mathrm{KSB}(\mathrm{Phg})$, and $\mathrm{KSB}(\mathrm{Glm})$, produced significant $(p<0.05)$ quantities of $K$ from an insoluble source (mica), while the isolates $\mathrm{KSBM}, \mathrm{KSB}(\mathrm{Sls}), \mathrm{KSB}(\mathrm{Trs})$ and $\mathrm{KSB}$ (Afr) produced significantly $(p<0.05)$ lower $\mathrm{K}$ quantities in comparison to standard at $20^{\circ} \mathrm{C}$ incubation temperature. However, the maximum quantity $(13.33 \mu \mathrm{g} \mathrm{K} / \mathrm{mL}$ broth) of $\mathrm{K}$ was solubilized by isolate $\mathrm{KSB}(\mathrm{Grz}), 63.9 \%$ more than that produced by the standard.

After twenty days of incubation at $0{ }^{\circ} \mathrm{C}, 1{ }^{\circ} \mathrm{C}, 3{ }^{\circ} \mathrm{C}, 5^{\circ} \mathrm{C}, 7{ }^{\circ} \mathrm{C}, 15^{\circ} \mathrm{C}$ and $20^{\circ} \mathrm{C}$ incubation temperatures, the $\mathrm{K}$ solubilization pattern by various isolates revealed that the standard (Bacillus mucilaginosus) exhibited solubilization activity only at and beyond $5{ }^{\circ} \mathrm{C}$ 
by producing $0.04,0.97,10.76$ and $15.33 \mu \mathrm{g} \mathrm{K} / \mathrm{mL}$ broth at $5{ }^{\circ} \mathrm{C}, 7{ }^{\circ} \mathrm{C}, 15^{\circ} \mathrm{C}$, and $20^{\circ} \mathrm{C}$, respectively (Table 4). Out of $13 \mathrm{KSB}$ isolates, only KSB (Smg), KSB (Drs), KSB (Gmr), KSB (Mng), and KSB (Grz) solubilized significantly $(p<0.05)$ higher K content than standard. However, a significant $(p<0.05)$ maximum of $23.38 \mu \mathrm{g} \mathrm{K} / \mathrm{mL}$ broth was solubilized by KSB (Grz), which is $52.5 \%$ more than the quantity solubilized by the standard isolate $20^{\circ} \mathrm{C}$. All the $\mathrm{K}$ solubilizing isolates showed almost stabilized $\mathrm{K}$ solubilization at $15^{\circ} \mathrm{C}$ and $20^{\circ} \mathrm{C}$ after 20 days of incubation that could be attributed to their psychrotrophic nature, while the standard isolate did not express any stabilization at $20^{\circ} \mathrm{C}$ after 20 days of incubation. The ability of KSB bacterial strains to show activity at lower temperatures could be attributed to their adaptability to these conditions [45] via several mechanisms such as cytoplasmic membrane fluidity, synthesis of cold shock proteins, and cryoprotectant genes [46]. Other studies have documented the psychrotrophic PGPR with mineral solubilization potential such as the solubilization of potassium, isolated from the Himalayan regions [42,47-49]. The solubilization of K-bearing rocks and minerals occurs through the release of various organic acids and enzymes, accompanied by acidolysis, complex lysis exchange reactions that lead to their conversion to a soluble form. The organic and inorganic acids can release the bound form of $\mathrm{K}$ from the unavailable and fixed forms, thereby improving the $\mathrm{K}$ availability to the plants [50-52].

\subsection{Production of Plant Growth-Promoting Substances}

All the K solubilizing isolates exhibited PGP activities such as the production of $\mathrm{HCN}$, ammonia, and IAA (Table 5). The isolates $\mathrm{KSB}(\mathrm{Smg}), \mathrm{KSB}(\mathrm{Drs}), \mathrm{KSB}(\mathrm{Pd}), \mathrm{KSB}(\mathrm{Sls})$, $\mathrm{KSB}(\mathrm{Trs}), \mathrm{KSB}(\mathrm{Grz})$, and $\mathrm{KSB}(\mathrm{Glm})$ produced significantly $(p<0.05)$ higher IAA content, as compared to standard isolate, with $\mathrm{KSB}(\mathrm{Grz})$ producing the highest content of $31.54 \mu \mathrm{M} / \mathrm{mL}$. The protease activity shown by all KSB isolates was non-significant in comparison to the standard. Only one isolate, $\operatorname{KSB}(\mathrm{Gmr})$, showed significantly $(p<0.05)$ higher $(5.2 \mu \mathrm{M} / \mathrm{mL})$ chitinase activity, similarly only two isolates, KSB(Grz) and KSB(Afr), showed significantly higher cellulase activities of 390 and $270 \mu \mathrm{M} / \mathrm{mL}$, respectively. The potential of cold tolerant bacteria to produce cold active enzymes and plant growth promoting substances has been also documented in an earlier study [53]. The capability of microbes to produce ammonia helps the plants to fulfill their nitrogen needs; the ample supply of ammonia to plants diminishes plant colonization by pathogenic microbes. Microorganisms produce ammonia via the hydrolyzation of urea into ammonia and $\mathrm{CO}_{2}$ [54], or through the fixation of atmospheric nitrogen into ammonia that inhibits the growth of pathogenic microbes [55]. Several rhizobacterial strains have been found capable of producing many volatile compounds such as hydrogen cyanide $(\mathrm{HCN})$ to control some soil-borne diseases like root rots in various crop plants [56-58]. Microorganisms such as Pseudomonas, Bacillus, Bradyrhizobium, Klebsiella Rhizobium sp. etc., were found to be involved in the biosynthesis of IAA through the formation of indole-3-pyruvic acid and indole-3-acetic aldehyde [59-63]. Growth improvement through enzyme activity such as proteases, chitinases, cellulases, phosphatases, etc., is another mechanism used by plant growth-promoting (PGP) bacteria via attacking pathogens through the excretion of cell wall degenerating enzymes $[56,64-67]$. KSB (Grz) isolate was noteworthy as it showed outstanding performance regarding the solubilization of insoluble $\mathrm{K}$, and can be utilized as a $\mathrm{K}$ biofertilizer in colder regions.

Table 5. Production of plant growth-promoting substances and enzymes by K solubilizing bacteria.

\begin{tabular}{ccccccc}
\hline Isolates & HCN & Ammonia & $\begin{array}{c}\text { IAA } \\
(\mu \mathbf{M} / \mathbf{m L})\end{array}$ & $\begin{array}{c}\text { Protease } \\
(\mu \mathbf{M} / \mathbf{m L})\end{array}$ & $\begin{array}{c}\text { Chitinase } \\
(\mu \mathbf{M} / \mathbf{m L})\end{array}$ & $\begin{array}{c}\text { Cellulase } \\
(\mu \mathbf{M} / \mathbf{m L})\end{array}$ \\
\hline Bacillus mucilaginosus & ++ & ++ & $27.00^{\mathrm{g}}$ & $525.12^{\mathrm{a}}$ & $5.10^{\mathrm{a}}$ & $250.55^{\mathrm{bc}}$ \\
KSB(Smg) & + & + & $27.22^{\mathrm{e}}$ & $325.74^{\mathrm{e}}$ & $3.70^{\mathrm{cd}}$ & $130^{\mathrm{e}}$ \\
KSB(Drs) & + & + & $31.00^{\mathrm{b}}$ & $417.24^{\mathrm{b}}$ & $2.90^{\mathrm{e}}$ & $121^{\mathrm{e}}$ \\
KSBM & & & $21.37^{\mathrm{k}}$ & $324.19^{\mathrm{f}}$ & $2.70^{\mathrm{e}}$ & $206^{\mathrm{cd}}$ \\
KSB(Gmr) & + & + & $17.09^{\mathrm{m}}$ & $313.09 \mathrm{~g}$ & $5.20^{\mathrm{a}}$ & $200^{\mathrm{e}}$ \\
\hline
\end{tabular}


Table 5. Cont.

\begin{tabular}{|c|c|c|c|c|c|c|}
\hline Isolates & $\mathrm{HCN}$ & Ammonia & $\begin{array}{c}\text { IAA } \\
(\mu \mathrm{M} / \mathrm{mL})\end{array}$ & $\begin{array}{l}\text { Protease } \\
(\mu \mathrm{M} / \mathrm{mL})\end{array}$ & $\begin{array}{l}\text { Chitinase } \\
(\mu \mathrm{M} / \mathrm{mL})\end{array}$ & $\begin{array}{l}\text { Cellulase } \\
(\mu \mathrm{M} / \mathrm{mL})\end{array}$ \\
\hline KSB(Mng) & - & + & $23.11^{j}$ & $310.23^{h}$ & $3.80 \mathrm{~cd}$ & $101^{\mathrm{e}}$ \\
\hline $\mathrm{KSB}(\mathrm{Pd})$ & + & + & $27.18^{f}$ & $297.12^{j}$ & $4.70^{\mathrm{b}}$ & $150^{e}$ \\
\hline KSB(Sls) & + & - & $29.32^{d}$ & $281.18^{\mathrm{k}}$ & $3.90^{c}$ & $185^{\mathrm{d}}$ \\
\hline KSB(Trs) & - & + & $31.44^{\mathrm{a}}$ & $330.72^{d}$ & $4.00^{\mathrm{c}}$ & $230^{b c d}$ \\
\hline $\mathrm{KSB}(\mathrm{Kgl})$ & + & + & $25.71^{\mathrm{i}}$ & $297.88^{i}$ & $2.90^{\mathrm{e}}$ & $137^{\mathrm{e}}$ \\
\hline KSB(Grz) & + & + & $31.54^{\mathrm{a}}$ & $397.20^{\mathrm{c}}$ & $3.80^{\mathrm{cd}}$ & $390^{a}$ \\
\hline KSB(Phg) & + & - & $26.78^{h}$ & $267.93^{\mathrm{m}}$ & $3.60^{d}$ & $229 \mathrm{bcd}$ \\
\hline $\mathrm{KSB}(\mathrm{Glm})$ & + & + & $30.31^{c}$ & $226.19^{n}$ & $4.00^{\mathrm{C}}$ & $115^{\mathrm{e}}$ \\
\hline KSB(Afr) & - & + & $19.32^{1}$ & $278.62^{1}$ & $3.50^{\mathrm{d}}$ & $270^{b}$ \\
\hline
\end{tabular}

* Used as standard. Different letters on the mean values represent significantly $(p<0.05)$ different values according to Duncan's Multiple Range Test (DMRT).

\subsection{Morphological and Biochemical Characteristics of the Isolate}

Based on morphological and biochemical features, the strain KSB-Grz was found to be rod-shaped and Gram-negative bacterium with white creamy, circular, entire margins, convex, smooth, and opaque colonies appearing on Aleksandrov's agar media within $2-3$ days of incubation at $20{ }^{\circ} \mathrm{C}$. Biochemical analysis results showed that KSB-Grz is positive for catalase, motility, and casein hydrolysis, and negative for citrate utilization, indole, methyl red, and the Voges Proskauer test. The isolate was found to belong to the species of Mesorhizobium sp.

\subsection{Molecular Characterization by $16 \mathrm{~S}$ rDNA Gene Sequencing Approach}

$16 \mathrm{~S}$ rDNA sequencing of the KSB-Grz strain presented utmost resemblance to the reference sequences from members of the Mesorhizobium sp. within the GenBank database. The phylogenetic tree of the KSB-Grz strain depicts its position within the Mesorhizobium genus (Figure 2). Based on these observations, the KSB-Grz strain was designated as Mesorhizobium sp. The gene sequences of the isolate were submitted to NCBI under the Accession number MH503776. The other bacterial isolates obtained from the cold deserts of Indian Himalaya and that exhibit multifunctional PGP activities at lower temperatures belong to Arthrobacter nicotianae, Brevundimonas terrae, Paenibacillus tylopili and Pseudomonas cedrina [68], Bacillus sp. [42].

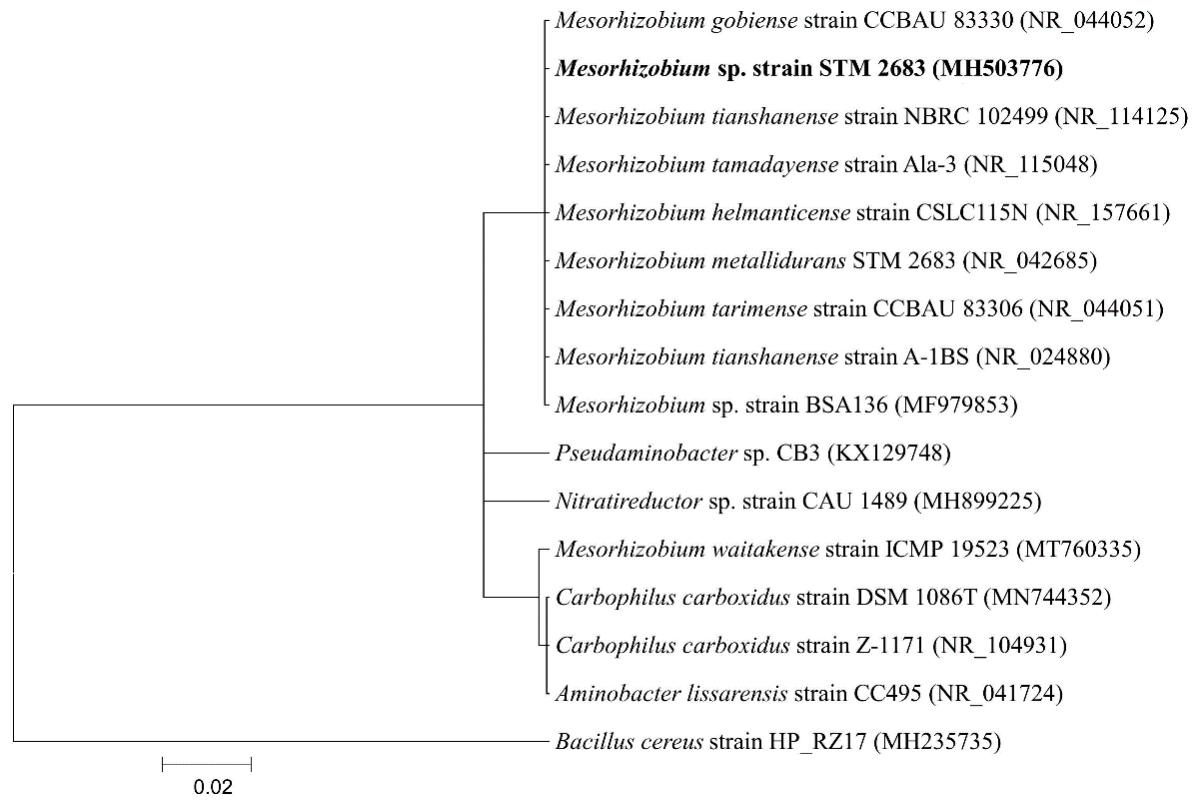

Figure 2. Phylogenetic tree of K-solubilizing KSB (Grz) strain based on 16S rDNA sequences. 


\section{Conclusions}

The results of the present study showed that out of a total 110 bacterial isolates, only 13 bacterial isolates showed the ability of potassium solubilization at lower temperature conditions $\left(0^{\circ} \mathrm{C}, 1^{\circ} \mathrm{C}, 3^{\circ} \mathrm{C}, 5^{\circ} \mathrm{C}, 7^{\circ} \mathrm{C}, 15^{\circ} \mathrm{C}\right.$ and $\left.20^{\circ} \mathrm{C}\right)$ under in-vitro conditions. However, the isolate $\mathrm{KSB}(\mathrm{Grz})$ was outstanding with respect to having the most significant and highest $\mathrm{K}$ solubilization potential, both qualitatively and quantitatively, in comparison to other strains and the standard strain (Bacillus mucilaginosus). All the KSB strains also possessed plant growth promoting activities by producing HCN, ammonia, IAA and lytic enzymes such as cellulase, protease and chitinase with the isolate KSB (Grz) producing IAA and cellulase significantly higher than those produced by the standard strain and the other strains, while the protease and chitinase were not significant. The potential isolate KSB (Grz) was identified as Mesorhizobium sp. via 16SrDNA sequencing.

Author Contributions: Conceptualization, Writing, Original draft, Supervision, Z.A.B.; Experimentation, Writing, B.H., B.H., T.A.S.; Writing - writing original draft and editing, Writing, proof reading and editing M.J.A., H.A.E.E., R.Z.S. and S.H.A. Fund acquisition; H.A.E.E., A.T.K.Z. and S.H.A. All authors have read and agreed to the published version of the manuscript.

Funding: This work was funded by The Researchers Supporting Project number (TURSP-2020/83), Taif University, Taif, Saudi Arabia and RMC, Universiti Teknologi Malaysia (UTM), Allcosmos Industries Sdn. Bhd. and Arif Effektiv Sdn. Bhd. with project No. R.J130000.7609.4C187. and R.J130000.7609.4C359.

Institutional Review Board Statement: Not Applicable.

Informed Consent Statement: Not Applicable.

Data Availability Statement: All the data is available in the manuscript.

Acknowledgments: The authors extend their appreciation to The Researchers Supporting Project number (TURSP-2020/83), Taif University, Taif, Saudi Arabia and RMC, Universiti Teknologi Malaysia (UTM), Allcosmos Industries Sdn. Bhd. and Arif Effektiv Sdn. Bhd. for providing financial support.

Conflicts of Interest: The authors declare that they have no conflict of interest that could influence the reported work.

Sample Availability: Samples of the compounds/isolates are available from the authors.

\section{References}

1. Gallegos-Cedillo, V.M.; Urrestarazu, M.; Álvaro, J.E. Influence of salinity on transport of nitrates and potassium by means of the xylem sap content between roots and shoots in young tomato plants. J. Soil Sci. Plant Nutr. 2016, 16, 991-998. [CrossRef]

2. Raji, M.; Thangavelu, M. Isolation and screening of potassium solubilizing bacteria from saxicolous habitat and their impact on tomato growth in different soil types. Arch. Microbiol. 2021, 203, 1-15. [CrossRef] [PubMed]

3. Pandey, D.; Kehri, H.K.; Zoomi, I.; Singh, U.; Chaudhri, K.L.; Akhtar, O. Potassium solubilizing microbes: Diversity, ecological significances and biotechnological applications. In Sustainable Development and Biodiversity; Springer Science and Business Media: Berlin/Heidelberg, Germany, 2020; pp. 263-286.

4. Shirale, A.O.; Meena, B.P.; Gurav, P.P.; Srivastava, S.; Biswas, A.K.; Thakur, J.K.; Somasundaram, J.; Patra, A.K.; Rao, A.S. Prospects and challenges in utilization of indigenous rocks and minerals as source of potassium in farming. J. Plant Nutr. 2019, 42, 2682-2701. [CrossRef]

5. Etesami, H.; Emami, S.; Alikhani, H.A. Potassium solubilizing bacteria (KSB): Mechanisms, promotion of plant growth, and future prospects a review. J. Soil Sci. Plant Nutr. 2017, 17, 897-911. [CrossRef]

6. Khati, P.; Mishra, P.K.; Parihar, M.; Kumari, A.; Joshi, S.; Bisht, J.K.; Pattanayak, A. Potassium solubilization and mobilization: Functional impact on plant growth for sustainable agriculture. In Microbial Rejuvenation of Polluted Environment; Springer Science and Business Media: Berlin/Heidelberg, Germany, 2020; pp. 21-39.

7. Binner, I.; Dultz, S.; Schellhorn, M.; Schenk, M. Potassium adsorption and release properties of clays in peat-based horticultural substrates for increasing the cultivation safety of plants. Appl. Clay Sci. 2017, 145, 28-36. [CrossRef]

8. Wen, Y.; You, J.; Zhu, J.; Hu, H.; Gao, J.; Huang, J. Long-term green manure application improves soil $\mathrm{K}$ availability in red paddy soil of subtropical China. J. Soils Sediments 2021, 21, 63-72. [CrossRef] 
9. Bhattacharya, S.; Bachani, P.; Jain, D.; Patidar, S.K.; Mishra, S. Extraction of potassium from K-feldspar through potassium solubilization in the halophilic Acinetobacter soli (MTCC 5918) isolated from the experimental salt farm. Int. J. Miner. Process. 2016, 152, 53-57. [CrossRef]

10. Torabian, S.; Farhangi-Abriz, S.; Qin, R.; Noulas, C.; Sathuvalli, V.; Charlton, B.; Loka, D. Potassium: A vital macronutrient in potato production-A review. Agronomy 2021, 11, 543. [CrossRef]

11. Madar, R.; Singh, Y.; Meena, M.; Das, T.; Paramesh, V.; Al-Mana, F.; Mattar, M.A.; Elansary, H.O. Residue and potassium management strategies to improve crop productivity, potassium mobilization, and assimilation under zero-till maize-wheat cropping system. Agriculture 2020, 10, 401. [CrossRef]

12. Rajawat, M.V.S.; Singh, R.; Singh, D.; Yadav, A.N.; Singh, S.; Kumar, M.; Saxena, A.K. Spatial distribution and identification of bacteria in stressed environments capable to weather potassium aluminosilicate mineral. Braz. J. Microbiol. 2020, 51, 751-764. [CrossRef]

13. Liu, J.N.; Cao, S.Y.; Chang, L.J.; Huang, J.D.; Zhao, X. Summarization of research status of potash feldspar in China. J. Bohai Univ. Nat. Sci. Ed. 2019, 40, 315-320.

14. Chen, Y.; Ye, J.; Kong, Q. Potassium-solubilizing activity of Bacillus aryabhattai SK1-7 and its growth-promoting effect on Populus alba L. Forests 2020, 11, 1348. [CrossRef]

15. Rao, C.S.; Srinivas, K. Potassium dynamics and role of non-exchangeable potassium in crop nutrition. Indian J. Fertil. 2017, $13,80-94$.

16. Tran, A.M. Potassium Fixation by Oxidized and Reduced Forms of Different Phyllo-Silicates. Ph.D. Thesis, Kansas State University, Manhattan, KS, USA, 2012.

17. Golestanifard, A.; Santner, J.; Aryan, A.; Kaul, H.-P.; Wenzel, W.W. Potassium fixation in northern Iranian paddy soils. Geoderma 2020, 375, 114475. [CrossRef]

18. Basu, A.; Prasad, P.; Das, S.N.; Kalam, S.; Sayyed, R.Z.; Reddy, M.S.; El Enshasy, H. Plant growth promoting rhizobacteria (PGPR) as green bioinculants: Recent developments, constraints, and prospects. Sustainability 2021, 13, 1140. [CrossRef]

19. Hamid, B.; Zaman, M.; Farooq, S.; Fatima, S.; Sayyed, R.; Baba, Z.; Sheikh, T.; Reddy, M.; El Enshasy, H.; Gafur, A.; et al. Bacterial plant biostimulants: A sustainable way towards improving growth, productivity, and health of crops. Sustainability 2021, 13, 2856. [CrossRef]

20. Sattar, A.; Naveed, M.; Ali, M.; Zahir, Z.A.; Nadeem, S.M.; Yaseen, M.; Meena, V.S.; Farooq, M.; Singh, R.; Rahman, M.; et al. Perspectives of potassium solubilizing microbes in sustainable food production system: A review. Appl. Soil Ecol. 2019, 133, 146-159. [CrossRef]

21. Sun, F.; Ou, Q.; Wang, N.; Guo, Z.X.; Ou, Y.; Li, N.; Peng, C. Isolation and identification of potassium-solubilizing bacteria from Mikania micrantha rhizospheric soil and their effect on M. micrantha plants. Glob. Ecol. Conserv. 2020, 23, e01141. [CrossRef]

22. Nosheen, S.; Ajmal, I.; Song, Y. Microbes as biofertilizers, a potential approach for sustainable crop production. Sustainability 2021, 13, 1868. [CrossRef]

23. Rajawat, M.V.S.; Ansari, W.A.; Singh, D.; Singh, R. Potassium solubilizing bacteria (KSB). In Microbial Interventions in Agriculture and Environment; Springer Science and Business Media: Berlin/Heidelberg, Germany, 2019; pp. 189-209.

24. Bakhshandeh, E.; Pirdashti, H.; Lendeh, K.S. Phosphate and potassium-solubilizing bacteria effect on the growth of rice. Ecol. Eng. 2017, 103, 164-169. [CrossRef]

25. Khanghahi, M.Y.; Pirdashti, H.; Rahimian, H.; Nematzadeh, G.; Sepanlou, M.G. Potassium solubilizing bacteria (KSB) isolated from rice paddy soil: From isolation, identification to K use efficiency. Symbiosis 2018, 76, 13-23. [CrossRef]

26. Xiao, Y.; Wang, X.; Chen, W.; Huang, Q. Isolation and identification of three potassium-solubilizing bacteria from rape rhizospheric soil and their effects on ryegrass. Geomicrobiol. J. 2017, 34, 873-880. [CrossRef]

27. Boubekri, K.; Soumare, A.; Mardad, I.; Lyamlouli, K.; Hafidi, M.; Ouhdouch, Y.; Kouisni, L. The screening of potassium- and phosphate-solubilizing actinobacteria and the assessment of their ability to promote wheat growth parameters. Microorganisms 2021, 9, 470. [CrossRef]

28. Khan, A.; Upadhayay, V.K.; Panwar, M.; Singh, A.V. Soil microbiota: A key bioagent for revitalization of soil health in hilly regions. In Microbiological Advancements for Higher Altitude Agro-Ecosystems \& Sustainability; Springer: Berlin/Heidelberg, Germany, 2020; pp. 183-200. [CrossRef]

29. Zahid, M.; Abbasi, M.K.; Hameed, S.; Rahim, N. Isolation and identification of indigenous plant growth promoting rhizobacteria from Himalayan region of Kashmir and their effect on improving growth and nutrient contents of maize (Zea mays L.). Front. Microbiol. 2015, 6, 207. [CrossRef] [PubMed]

30. Joshi, P.; Joshi, G.K.; Mishra, P.K.; Bisht, J.K.; Bhatt, J.C. Diversity of cold-tolerant phosphate solubilizing microorganisms from the northwestern Himalayas. In Bacterial Diversity in Sustainable Agriculture, Sustainable Development and Biodiversity; Maheshwari, D.K., Ed.; Springer: Berlin/Heidelberg, Germany, 2014; pp. 227-264.

31. Available online: http://www.weatherbase.com (accessed on 30 December 2017).

32. Meena, V.S.; Maurya, B.R.; Verma, J.P.; Aeron, A.; Kumar, A.; Kim, K.; Bajpai, V.K. Potassium solubilizing rhizobacteria (KSR): Isolation, identification, and K-release dynamics from waste mica. Ecol. Eng. 2015, 81, 340-347. [CrossRef]

33. Sadiq, H.M.; Jahangir, G.Z.; Nasir, I.A.; Iqtidar, M.; Iqbal, M. Isolation and characterization of phosphate-solubilizing bacteria from rhizosphere soil. Biotechnol. Biotechnol. Equip. 2013, 27, 4248-4255. [CrossRef] 
34. Bagyalakshmi, B.; Ponmurugan, P.; Balamurugan, A. Potassium solubilization, plant growth promoting substances by potassium solubilizing bacteria (KSB) from southern Indian Tea plantation soil. Biocatal. Agric. Biotechnol. 2017, 12, 116-124. [CrossRef]

35. Passari, A.K.; Mishra, V.K.; Gupta, V.K.; Yadav, M.K.; Saikia, R.; Singh, B.P. In Vitro and In Vivo plant growth promoting activities and DNA fifingerprinting of antagonistic endophytic actinomycetes associates with medicinal plants. PLoS ONE 2015, 10, 0139468. [CrossRef]

36. Ashfaq, M.; Hassan, H.M.; Ghazali, A.H.A.; Ahmad, M. Halotolerant potassium solubilizing plant growth promoting rhizobacteria may improve potassium availability under saline conditions. Environ. Monit. Assess. 2020, 192, 697. [CrossRef]

37. Joshi, G.; Kumar, V.; Brahmachari, S.K. Screening and identification of novel halotolerant bacterial strains and assessment for insoluble phosphate solubilization and IAA production. Bull. Natl. Res. Cent. 2021, 45, 1-12. [CrossRef]

38. Zhou, C.; Qin, H.; Chen, X.; Zhang, Y.; Xue, Y.; Ma, Y. A novel alkaline protease from alkaliphilic Idiomarina sp. C9-1 with potential application for eco-friendly enzymatic dehairing in the leather industry. Sci. Rep. 2018, 8, 16467. [CrossRef] [PubMed]

39. Subramanian, K.; Sadaiappan, B.; Aruni, W.; Kumarappan, A.; Thirunavukarasu, R.; Srinivasan, G.P.; Subramanian, M. Bioconversion of chitin and concomitant production of chitinase and $\mathrm{N}$-acetylglucosamine by novel Achromobacter xylosoxidans isolated from shrimp waste disposal area. Sci. Rep. 2020, 10, 11898. [CrossRef]

40. Pramanik, S.K.; Mahmud, S.; Paul, G.K.; Jabin, T.; Naher, K.; Uddin, S.; Zaman, S.; Saleh, A. Fermentation optimization of cellulase production from sugarcane bagasse by Bacillus pseudomycoides and molecular modeling study of cellulase. Curr. Res. Microb. Sci. 2021, 2, 100013. [CrossRef]

41. Sarikhani, M.R.; Oustan, S.; Ebrahimi, M.; Aliasgharzad, N. Isolation and identification of potassium-releasing bacteria in soil and assessment of their ability to release potassium for plants. Eur. J. Soil Sci. 2018, 69, 1078-1086. [CrossRef]

42. Yadav, A.N.; Sachan, S.G.; Verma, P.; Saxena, A.K. Bioprospecting of plant growth promoting psychrotrophic Bacilli from the cold desert of north western Indian Himalayas. Indian J. Exp. Biol. 2016, 54, 142-150.

43. Ahmad, M.S.; Zargar, M.Y. Characterization of potassium solubilizing bacteria (KSB) in rhizospheric soils of apple (Malus domestica borkh.) in temperate Kashmir. J. Appl. Life Sci. Int. 2017, 15, 1-7. [CrossRef]

44. Yadav, N.; Yadav, A.N. Biodiversity and biotechnological applications of novel plant growth promoting methylotrophs. J. Appl. Biotechnol. Bioeng. 2018, 5, 342-344. [CrossRef]

45. Verma, A.; Patidar, Y.; Vaishampayan, A. Isolation and purification of potassium solubilizing bacteria from different regions of India and its effect on crop's yield. Indian J. Microbiol. Res. 2016, 3, 483-488.

46. Pandey, A.; Yarzábal, L.A. Bioprospecting cold-adapted plant growth promoting microorganisms from mountain environments. Appl. Microbiol. Biotechnol. 2019, 103, 643-657. [CrossRef] [PubMed]

47. D'Amico, S.; Collins, T.; Marx, J.-C.; Feller, G.; Gerday, C. Psychrophillic microorganisms: Challenges for life. EMBO Rep. 2006, 7, 385-389. [CrossRef]

48. Verma, P.; Yadav, A.N.; Shukla, L.; Saxena, A.K.; Suman, A. Alleviation of cold stress in wheat seedlings by Bacillus amyloliquefaciens IARIHHS2-30, an endophytic psychrotolerant K-solubilizing bacterium from NW Indian Himalayas. Natl. J. Life Sci. 2015, 12, 105-110.

49. Yadav, A.N.; Kour, D.; Sharma, S.; Sachan, S.G.; Singh, B.; Chauhan, V.S.; Sayyed, R.Z.; Kaushik, R.; Saxena, A.K. Psychrotrophic microbes: Biodiversity, mechanisms of adaptation, and biotechnological implications in alleviation of cold stress in plants. In Plant Growth Promoting Rhizobacteria for Sustainable Stress Management; Springer Science and Business Media: Berlin/Heidelberg, Germany, 2019; pp. 219-253.

50. Rajawat, M.V.S.; Singh, R.; Singh, D.; Saxena, A.K. Psychrotrophs of the genus Janthinobacterium with potential to weather potassium aluminosilicate mineral. 3 Biotech 2019, 9, 142. [CrossRef]

51. Nirmala, J.L.I.; Surendranatha, R. Essential nutrients solubilization ability of fluorescent pseudomonads and their multinutrient management. Int. J. Sci. Res. 2015, 4, 43-49.

52. Bahadur, I.; Maurya, B.R.; Meena, V.S.; Saha, M.; Kumar, A.; Aeron, A. Mineral release dynamics of tricalcium phosphate and waste muscovite by mineral-solubilizing rhizobacteria isolated from indo-gangetic plain of India. Geomicrobiol. J. 2016, 34, 454-466. [CrossRef]

53. Berde, C.V.; Gawde, S.S.; Berde, V.B. Potassium solubilization: Mechanism and functional impact on plant growth. In Sustainable Development and Biodiversity; Springer: Berlin/Heidelberg, Germany, 2021; pp. 133-148.

54. Yadav, A.N.; Verma, P.; Sachan, S.G.; Kaushik, R.; Saxena, A.K. Psychrotrophic microbiomes: Molecular diversity and beneficial role in plant growth promotion and soil health. In Microorganisms for Green Revolution; Panpatte, D., Jhala, Y., Shelat, H., Vyas, R., Eds.; Springer: Berlin/Heidelberg, Germany, 2018; pp. 197-240.

55. Mazumdar, D.; Saha, S.P.; Ghosh, S. Isolation, screening and application of a potent PGPR for enhancing growth of chickpea as affected by nitrogen level. Int. J. Veg. Sci. 2020, 26, 333-350. [CrossRef]

56. Richard, P.O.; Adekanmbi, A.O.; Ogunjobi, A.A. Screening of bacteria isolated from the rhizosphere of maize plant (Zea mays L.) for ammonia production and nitrogen fixation. Afr. J. Microbiol. Res. 2018, 12, 829-834.

57. Vinay, J.U.; Naik, M.K.; Rangeshwaran, R.; Chennappa, G.; Shaikh, S.S.; Sayyed, R.Z. Detection of antimicrobial traits in fluorescent pseudomonads and molecular characterization of an antibiotic pyoluteorin. 3 Biotech 2016, 6, 227. [CrossRef] [PubMed]

58. Kusale, S.P.; Attar, Y.C.; Sayyed, R.Z.; Malek, R.A.; Ilyas, N.; Suriani, N.L.; El Enshasy, H.A. Production of plant beneficial and antioxidants metabolites by Klebsiella variicola under salinity stress. Molecules 2021, 26, 1894. [CrossRef] [PubMed] 
59. Shaikh, S.S.; Sayyed, R.Z. Role of plant growth-promoting rhizobacteria and their formulation in biocontrol of plant diseases. In Plant Microbes Symbiosis: Applied Facets; Springer: New Delhi, India, 2015; pp. 337-351.

60. Jabborova, D.; Wirth, S.; Kannepalli, A.; Narimanov, A.; Desouky, S.; Davranov, K.; Bahkali, A.H. Co-inoculation of rhizobacteria and biochar application improves growth and nutrientsin soybean and enriches soil nutrients and enzymes. Agronomy 2020, 10, 1142. [CrossRef]

61. Jadhav, H.P.; Sayyed, R.Z.; Shaikh, S.S.; Bhamre, H.M.; Sunita, K.; El Enshasy, H.A. Statistically designed bioprocess for enhanced production of alkaline protease in Bacillus cereus HP_RZ17. J. Sci. Ind. Res. 2020, 79, 491-498.

62. Kusale, S.P.; Attar, Y.C.; Sayyed, R.Z.; El Enshasy, H.; Hanapi, S.Z.; Ilyas, N.; Marraiki, N. Inoculation of Klebsiella variicola alleviated salt stress and improved growth and nutrients in wheat and maize. Agronomy 2021, 11, 927. [CrossRef]

63. Islam, S.; Akanda, A.M.; Prova, A.; Islam, T.; Hossain, M. Isolation and identification of plant growth promoting rhizobacteria from cucumber rhizosphere and their effect on plant growth promotion and disease suppression. Front. Microbiol. 2016, 6, 1360. [CrossRef]

64. Baba, Z.A.; Aziz, M.A.; Sheikh, T.A.; Sheikh, F.A.; Bhat, Z.A.; Khan, S.; Saher, T.; Hamid, B. Studies on soil health and plant growth promoting potential Rhizobium isolates. Emir. J. Food Agric. 2015, 27, 423-429. [CrossRef]

65. Li, S.; Zhang, B.; Zhu, H.; Zhu, T. Cloning and expression of the chitinase encoded by ChiKJ406136 from Streptomyces sampsonii (Millard \& Burr) waksman KJ40 and its antifungal effect. Forests 2018, 9, 699. [CrossRef]

66. Bhagwat, A.; Collins, C.H.; Dordick, J.S. Selective antimicrobial activity of cellulolytic enzymes in a bacterial consortium. Appl. Microbiol. Biotechnol. 2019, 103, 7041-7054. [CrossRef]

67. Baba, Z.A.; Sheikh, T.; Hamid, B. Functional diversity of culturable phosphate solubilizing fluorescent pseudomonads. Indian J. Agric. Res. 2014, 48, 472. [CrossRef]

68. Yadav, A.N.; Sachan, S.G.; Verma, P.; Saxena, A.K. Prospecting cold deserts of north western Himalayas for microbial diversity and plant growth promoting attributes. J. Biosci. Bioeng. 2015, 119, 683-693. [CrossRef] [PubMed] 